\title{
AZERBAYCAN BANKACILIK SEKTÖRÜNÜN CAMELS ANALIZİ: YABANCI SERMAYELİ 10 BANKA
}

$* * *$

\section{CAMELS ANALYSIS OF AZERBAIJAN BANKING SECTOR: 10 BANKS WITH FOREIGN CAPITAL}

\begin{abstract}
Öğr. Gör. Turan AHMEDOV
ORCID: 0000-0002-9305-6059

Azerbaycan Devlet İktisat Üniversitesi

Türk Dünyası İşletme Fakültesi, İktisat ve İşletme Bölümü ahmedovturan@gmail.com

Uzm. Elsever MEMMEDOV

ORCID: 0000-0001-8969-9513

Azerbaycan Devlet İktisat Üniversitesi Türk Dünyası İşletme Fakültesi, İktisat ve İşletme Bilim Uzmanı elsever_mamedoff@mail.ru

$\ddot{O} z$

Çalışmada performans ölçme ve değerlendirme konularına değinilmiş, aynı zamanda CAMELS yöntemi hakkında bilgi verilmiştir. Azerbaycan bankacılık yapısı ve temel özellikleri incelenmiş ve ülkenin makro iktisadi göstergeleri üzerinde durulmuştur. Banka performansının ölçülmesinde sıkça kullanılan CAMELS Analizi yöntemi ile Azerbaycan bankacılık sektöründe faaliyet gösteren bankaların performans ölçümü gerçekleştirilmiştir. Sektörde faaliyet gösteren yabancı sermayeli 10 bankanın finansal rasyoları ile referans değerler bazında inceleme yapılmuş ve yorumlanmuştır.
\end{abstract}

Anahtar Kelimeler: Bankacılık sektörü, Performans Ölçümü, CAMELS Analizi.

Jel Kodlart: G24, G20.

\begin{abstract}
In the study, the subjects of performance measurement and evaluation have been mentioned and information about CAMELS ranking system has been worked on. The structure of Azerbaijan banking system and its basic features have been examined while its macroeconomic indicators have been emphasised. Performance measurement of commercial banks which are active in Azerbaijan banking sector has been conducted by CAMELS Analysis, which is a frequently used method in the measurement of banking performance. Financial ratios of 10 banks with foreign capital in the sector, examining their reference on the basis of values.
\end{abstract}

Keywords: Banking System, Performance, Performance Measurement, CAMELS Analysis.

Jel Codes: G24, G20. 


\section{GíRIŞ}

Ülkede mali sistemimizin temelini oluşturan bankalar tasarrufların, fon fazlası olanlardan alınıp fon açığı olan kamu ya da özel kuruluşlara aktarılmasını sağlamada aracılık görevi üstlenirler. Bu yönüyle sağlanan kaynakların verimli ve kârlı alanlara aktarılması, ülke ekonomisine olumlu yönde etki yapmakta ve ekonomik kalkınmaya dinamizm katmaktadır. Her ülkede olduğu gibi ülkemizde de ekonomik, sosyal ve siyasi gelişmeler bankacılık sektörünün niteliklerinde, yapılanmasında ve yönlendirilmesinde etkili olmaktadır. Küreselleşmenin etkisiyle ekonomik faaliyetlerin çeşitlenmesi ve bunun neticesi olarak artan finansman ihtiyacına cevap verebilmek için bankacılık sektörünün sürekli gelişme içinde olması beklenmektedir. Ülke ekonominin sağlıklı işleyişi açısından büyük önem taşıyan bankacılık sektörü, ülkemiz ekonomisinde meydana gelen değişimlere en hassas olan sektörlerden biri haline gelmiştir. Bu bağlamda ülkede meydana gelen krizler ekonominin tamamını etkilerken Azerbaycan bankacılık sisteminin kırılgan ve belirsiz yapısı üzerinde de oldukça olumsuz sonuçlar doğurmuştur. Bu olumsuzlukların sonucu olarak da sektörde tasfiye ve birleşmeler yaşanmış ve sektörle ilgili yeni düzenlemeler ortaya konmuştur. Bankacılık sektörünün sergilediği performans ülkedeki tüm ekonomik birimleri etkilemektedir. Böylece bankacılık sektörünün performansının ölçülmesi ve denetiminin yapılması önem taşımaktadır. Günümüzde pek çok ülke bankacılık kurumlarının performanslarını değerlendirilmesi ile ilgili değişik sistemler kullanmaktadırlar. 1980’li yıllarda ilk olarak ABD gözetim ve denetim otoriteleri tarafından bankaların yerinde denetimi için geliştirilen CAMELS derecelendirme sistemi Azerbaycan'da son zamanlarda bankaların performanslarının ölçülmesinde kullanılmaktadır. Çalışmanın birinci bölümünde denetim kurumlarının bankaları izlemede kullandıkları yöntemler hakkında bilgiler verilmiş performans endeksinin hesaplanmasında kullanılan CAMELS yöntemi ayrıntılı olarak açıklanmıştır. İkinci bölümde, Azerbaycan ekonomisinin ve Azerbaycan Bankacılık sisteminin tarihi ve genel görünümü hakkında bilgiler verilmiş ve incelemenin yapıldığı 2010-2014 yılları arasında bankaların ve ekonominin gelişimi tablolar yardımıyla açıklanmıştır. $\mathrm{Bu}$ araştırmada uygulama kısmında, bankacılık sektörünün nasıl performans sergilediğini tespit etmek amacıyla CAMELS değerlendirme sistemi aracılığıyla Azerbaycan'da faaliyet gösteren 10 adet yerli sermayeli bankaların performans analizi yapılmış ve elde edilen sonuçlar karşılaştırılarak değerlendirilmiştir. CAMELS değerlendirme sisteminin geleneksel yöntemi olan 1-5 arası ölçek kullanması basit ve dar çerçeveli olduğundan dolayı kullanılması uygun görülmemektedir. Bunun yerine seçilen göstergeler öncelikle ait oldukları bileşende endekse dönüştürülmüştür. Daha sonraki aşamada ise söz konusu endekslerin ağırlıklı ortalamaları alınarak bileşik endeks elde edilmiştir.

\section{LITERATÜR TARAMASI}

Kandemir ve Demirel Arıcı (2013) Türkiye'de faaliyet gösteren mevduat bankalarının mülkiyet yapılarına göre gruplandırılarak 2001-2010 yılları arasındaki performanslarının grup bazında karşılaştırmalı olarak analiz etmişler. Yapılan analiz sonucunda 2001 bankacılık krizi sonrasında mevduat bankalarının yüksek sermaye yeterlilik ve likidite oranlarına sahip oldukları ve dolayısıyla olası krizlere karşı oldukça temkinli hareket ettikleri tespit edilmiştir. İncelenen dönemde, yabancı sermayeli mevduat bankaları aktif kalitesi ve yönetim kalitesi açısından en iyi performansı gösteren grup olurken, piyasa risklerine karşı diğer gruplara göre daha duyarlı olduklarını tespit edilmişlerdir.

Türker Kaya (2001), Bankaların CAMELS performanslarındaki farklılaşmayı araştırmak için yapılan non-parametrik test sonuçlarına göre; bankaların genel CAMELS değerleri 2000 yılında 1997 yılına göre sistematik olarak farklılaşmıştır. Bu farklılaşmanın kaynağının TMSF kapsamındaki bankalardan kaynaklandığı tespit edilmiştir. TMSF dışındaki bankaların CAMELS değerlerinde ise bu iki yıl arasında belirgin bir farklılaşma tespit edilememiştir. 
Ege, Topaloğlu ve Karakozak (2015), çalışmasında CAMELS analiz yöntemi ile Türk bankacılık sisteminde yer alan kamu, özel ve yabancı sermayeli mevduat bankalarının mali durumlarını tespit etmek amacıyla 2002-2010 dönemine ilişkin veriler kullanılarak banka gruplarının karşılaştırmalı analizini yapılmışlardır. Analiz bulguları doğrultusunda sermaye yeterliliği, piyasa risklerine duyarlılık ve yönetim yeterliliği açısından kamu sermayeli mevduat bankalarının; karlılık açısından özel sermayeli mevduat bankalarının; aktif kalitesi ve likidite açısından ise yabancı sermayeli mevduat banklarının diğer banka gruplarına göre daha iyi durumda oldukları tespit edilmiştir.

Çağil ve Mukhtarov (2014), 2007-2010 döneminde Azerbaycan'da faaliyette bulunan yerli ve yabancı sermayeli bankalarda CAMELS analizinin uygulanması ve çeşitli önerilerde bulunmuşlar. Analiz sonuçlarına göre gerek yerli sermayeli gerekse yabancı sermayeli bankaların Azerbaycan bankacılık sektörünün yaşadığ 1 birtakım sorunlar, hukuki ve teknolojik altyapının yeterli olmaması, tasarruf birikiminin yetersizliği, dışa bağımlı kaynak yapısı, etkin iç denetim ve kontrol sisteminin olmaması, sektörü bilen nitelikli personelin çok az olması, borçlanma maliyetlerinin ülkenin ekonomik durumuna da bağlı olarak çok yüksek olması, yeterince çeşitlendirilmemiş finansal ürün ve varlıkların bulunmaması dezavantajları arasında gösterilmektedir.

\section{AZERBAYCAN BANKACILIK SEKTÖRÜ}

Azerbaycan, eski Sovyetler Birliği ülkeleri içerisinde yer alan ve bu ülkeler içerisinde bağımsılı̆̆ını elde etmesi ile birlikte serbest pazar ekonomisine geçme hazırlıklarını da başlatan bir Türk Cumhuriyetidir. Pazar ekonomisi ve hür dünyanın diğer ülke kurumlarının ülke içinde yer alması konusundaki çalışma ve uygulamalar devam etmektedir.

$\mathrm{Bu}$ çalışmalar içinde en önemli yer, bankacılık ve mali kurumlar alanındaki düzenlemelerdir. Çünkü entegre olunmaya çalışılan pazar ekonomisi sisteminin temel unsurları bankalar ve mali kurumlardır. Serbest bankacılık sistemini gerçekleştirmeden ve mali kurumları oluşturmadan, piyasa sistemine sağlıklı bir geçiş yapmak mümkün değildir. Azerbaycan yetkilileri de bu düşünceleri benimsemişler ve ilk yenilikleri bankacılık ve merkez bankacılığı alanında yapmışlardır. Arka arkaya yürürlüğe koydukları kanunlarla, modern anlamda bir merkez bankası oluşturmaya girişmişler ve özel bankaların kuruluşlarını kolaylaştırarak tek kesimli banka sisteminden iki kesimli banka sistemine adım atmışlardır (Akdiş, 1995:s103).

Azerbaycan Cumhuriyeti bankacılı sisteminin faaliyeti "Banklar Hakkında" kanunla düzenlenmiştir. Kanuna göre ülkenin banka sistemi iki basamaklıdır - Azerbaycan Cumhuriyetinin Merkezi Bankasından ve kredi kurumlarından ibarettir. Ana basamak - Merkez Bankası ve faaliyeti Azerbaycan Cumhuriyeti Anayasası, «Azerbaycan Cumhuriyetinin Merkez Bankası Hakkında» Kanun, Medeni Kanun ve diğer normatif hukuk düzenlenmeleriyle düzenlenir. Mevzuat gereği Merkez Bankası banka faaliyetine lisans verir ve tanzim eder, kanunla belirlenmiş şekilde banka faaliyeti üzerinde denetimi gerçekleştirir. Banka sisteminin ikinci basamağı kredi kurumlarıdır. Kredi kurumlarının faaliyeti Cumhuriyetinin Anayasası, "Bankalar Hakkında" Kanun, Medeni Kanun, "Azerbaycan Cumhuriyetinin Merkez Bankası Hakkında", "Banka Dışı Kredi Kurumları Hakkında" ve "Kredi Birlikleri Hakkında" kanunlar vs. normatif hukuk düzenlemeleriyle düzenlenir. Bank sektörünün gelişim düzeyinin toplam aktiflerin GSMH'ye oranıyla ölçülür. Eksperlerin hesaplamalarına göre, ekonomik kalkınma düzeyi düşük ülkelerde banka sektörünün toplam aktiflerinin GSMH'deki \%5'inden fazla değildir. Azerbaycan'da bank sektörünün toplam aktiflerinin GSYH'de yaklaşı payı \%32'e eşittir.

2010 yılında banka aktiflerinin toplamı 13290,81 milyon manat olmuştur. Ortalama banka aktifi 295,35 milyon manat olmuştur (azerbaijans.com, 10.01.2017). 2014 yılı itibariyle ülkenin bankacılık 
sisteminde temerküzleşme düzeyi \%58,2'dir. Beş banka (Beynelhalk Bank, Kapital bank, Bank Standart, Halk bank ve Paşabank) aktifleri toplam aktiflerin \%58,2'ini oluşturur. Ülkedeki bankaların kayıtlı sermayelerinin \%39,2'i, depozitolarının \%60'1, kredi portföylerinin \%54'ü bu beş bankaya aittir. Bank sisteminde tek devlet bankası Beynelhalk Banka'dır. 2014 yılı verilerine göre aktiflerin \%41,6's1 Beynelhalk Bankaya aittir. Ülkede kredi portföyünün \%41'i, depozitoların \%36'sı bu banka tarafından yönetilmektedir. Geri kalan 20 banka pazar payı \%5'den de azdır. Bu bankların aktifleri toplam 639 milyon manat, ortalama her bankanın aktifi tahmini 32 milyona eşittir. Ülkedeki kredi portföyünün $\% 8,3$ 'i, depozitoların $\% 2,5$ 'i bu bankalara aittir. Ortalama her bir bankanın kredi portföyü 38 milyon manat, depozito portföyü 6,9 milyon manattır. Resmi bilgilere göre 2016 yılı itibariyle ülkede 41 banka faaliyettedir. Onların biri devlet, 40'1 özeldir. Özel bankaların 21'i yabancı sermayelidir (http://www.banks.az, 10.01.2017).

Şekil 1: Banka Olmayan Kredi Teşkilatların Genel Göstericileri (mln. manat)

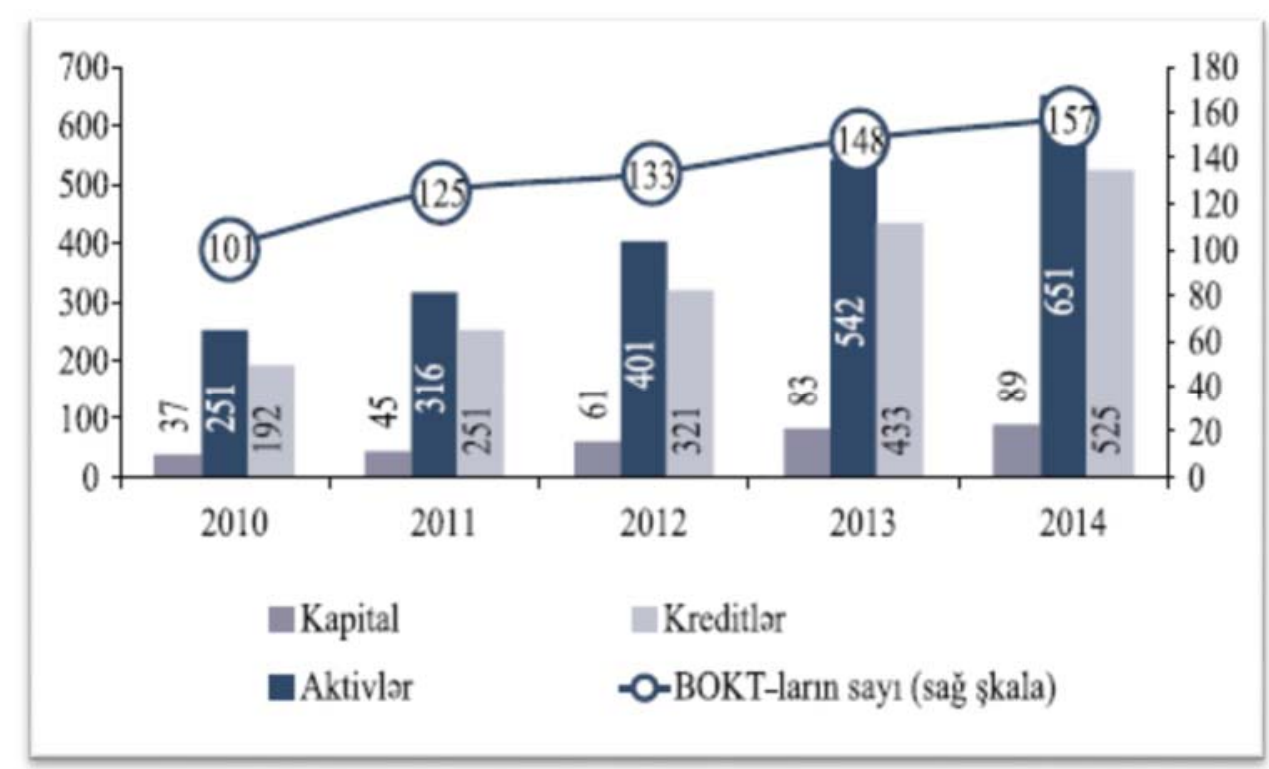

Kaynak: Azerbaycan Cumhuriyeti Merkez Bakası, 2014 yıllık rapor, Mart, 2015

\section{CAMELS DERECELENDİRME SISTEMININ OLUŞTURULMASI}

CAMELS derecelendirme sistemi oluşturulurken ilk olarak bankalar her bir CAMELS bileşeni için değerlendirilmektedir. Bunun için çeşitli finansal rasyolar kullanılmakta ve derecelendirme 1-5 arası bir ölçek üzerinden yapılmaktadır. Buna göre "1" ilgili bileşende en iyi performans gösteren kurumları temsil etmekte ve artan derece kötüleşen durumu göstermektedir. Bileşenler belirlenen şekilde ayrı ayrılıkta hesaplandıktan sonra bu bileşenlerin ağırlıklı ortalaması o bankanın genel notunu vermektedir (Muhtarov, 2012:55). Söz konusu değerlendirme yapılırken ağırlıklar tamamen denetçinin kontrolünde olduğundan; bankanın yapısı, büyüklüğü, genel ve/veya bankaya özel konular dikkate alınmaktadır. Bankaların hesaplanan CAMELS notu da yine 1 ila 5 arasında oluşmaktadır.

Bankaların yerinde denetimi için denetim kurumları tarafından kullanılan CAMELS (Sermaye Yeterliliği, Aktif Kalitesi, Yönetim Yeterliliği, Karlılık, Likidite, Piyasa Riskine Duyarlılık) bileşenlerinden oluşmaktadır. Aşağıda bu bileşenler ve bunları değerlendirirken dikkate alınan kriterler açıklanmıştır (Muhtarov, 2012:99):

- “1” her yönden güçlü bankaları (bankanın CAMELS'ı oluşturan her bir bileşen için notu 1 ya da 2 olmali),

- “2” genel olarak güçlü bankaları (her bir bileşen değeri 3'den kötü olmamalı), 
- “3” Bankanın etkinliğiyle ilgili sorunlar olduğunu, tatminkâr bir yapıda çalışmadığını ve olası şoklara karşı yeterince dayanıklı olmadığını ve denetçilerin sorunlu alanlara eğilmesi gerektiğini,

- "4" genel olarak ciddi problemleri olan ve finansal/yönetimsel bozulmaların yaşandığı ve dolayısıyla performansı kötü olan bankaları,

- "5" Çok ciddi mali / yönetimsel problemleri olup, yüksek batma riski taşıyan bankaları temsil etmektedir.

CAMELS'i meydana getiren bileşenler oluşturulurken aynı finansal rasyo birden fazla bileşende kullanılabilmektedir. Örneğin, bankaların aktif yapılarını değerlendirirken kullanılan rasyoların bir kısmı aynı anda hem karlılığı, hem likiditeyi hem de aktif kalitesini etkileyebilmektedir.

Her bileşen değeri atanırken yönetimin riskleri tespit etme, ölçme, izleme ve kontrol etme yeteneği de dikkate alınmalıdır. Ancak, kurumun büyüklüğüne, karmaşıklığına ve risk profiline bağlı olarak bu uygun yönetim uygulamalarının bankacılık kurumları arasında farklılık gösterdiği görülmektedir. Sadece geleneksel bankacılık faaliyetleri yürüten küçük çaplı kurumlar ve bu kurumların günlük operasyonlarının gözetiminde ve yönetiminde aktif olarak yer alan yönetim kurulu ve üst düzey yöneticiler için, oldukça temel, fazla detaya inmeyen yönetim sistemleri ve kontrolleri yetersiz olabilmektedir. Diğer yandan, daha büyük kurumlarda ayrıntılı ve yapısal yönetim sistemleri ve kontrolleri; bu kurumların daha geniş alana yayılmış finansal faaliyetlerinin belirlenmesi ve üst düzey yöneticilere günlük faaliyetlerin gözlenmesi ve yönetimin gereksinim duyduğu bilginin sağlanması için gereklidir. Daha az risk alıcı faaliyetlerle meşgul olan daha az karmaşık yapılı kurumlarda, kapsamlı veya yüksek derecede biçimselleştirilmiş yönetim sistemleri ve kontroller güçlü veya tatminkâr derecelerin elde edilmesi için gerekli görülmemiştir (Federal Deposit Insurance Corporation, 2011:s.1).

\subsection{Analizin Amacı ve Kapsamı}

Azerbaycan bankacılık sektörünün etkin ve verimli çalışması ülke ekonomisi açısından büyük önem taşımaktadır. Çünkü diğer ekonomik sektörlerden farklı olarak bankacılık sektörü kaynak dağılımını belirleyen finansal aracılık görevi üstlenmiştir. Bu durum bankacılık sektörünü, ülkenin ekonomik gelişmesinde merkezi bir konuma getirmiştir.

Bundan dolayı bankacılık sektöründe meydana gelecek bir olumsuzluk ülke ekonomisinde ciddi zararlara sebep olabilir. Bu bağlamda yakın geçmişte ülkemizde yaşanmış olan krizlerin temel nedenlerinden biri olarak finans sistemimizin temelini oluşturan ticari bankaların finansal yapılarının yeterince güçlü olmaması ve bunun yanında bu bankaların etkin ve verimli çalışma yapısına sahip olmamaları gösterilebilir. Bu nedenle bankacılık sektörünün düzenli bir şekilde kontrolü kötü tecrübelerin yaşanması olasılıklarını azaltmış olacaktır. Çalışmanın bu bölümünde CAMELS yöntemi aracılığıyla Azerbaycan'daki ticari bankaların performansı ortaya konmaktadır.

Çalışmada, Azerbaycan Bankacılık Sektörünün performansının genel hatlarıyla takibinin yapılmasında bileşik gösterge yaklaşımı temelleri üzerine kurulan Bankacılık Sektörü Performans Endeksi kullanılması amaçlanmıştır. Çalışma kapsamında, Azerbaycan'da faaliyet gösteren ve verilerine ulaşılabilen 10 yabancı sermayeli ticari bankanın 2010-2014 yılları arasındaki performansları CAMELS analizi aracılığıyla yapılmaktadır. Söz konusu bankalar piyasada aktif büyüklüklerine göre Azerbaycan bankacılık sektörünün yaklaşık \% 75'ini oluşturmaktadır. Analizde kullanılan yerli sermayeli ticari bankaların aktif büyüklükleri yaklaşık \%58'dir. Bu nedenle bu bankaların sektörü temsil yetkisi yüksektir. 2010 dönemi öncesi Azerbaycan bankalarına ait verilere ulaşılamadığından analiz dönemi 2010-2014 aralığı olarak incelenmiştir. 


\subsection{Analizin Veri Seti ve Metodolojisi}

Bu çalışmada, Türk Bankacılık Sektörü Performans Endeksi'nin hesaplanmasında CAMELS analizi kullanılacaktadır. CAMELS değerlendirme sisteminin geleneksel yöntemi olan 1-5 arası ölçek kullanması basit ve dar çerçeveli olduğundan dolayı kullanılması uygun görülmemektedir. Bunun yerine seçilen göstergeler öncelikle ait oldukları bileşende endekse dönüştürülmüştür. Daha sonraki aşamada ise söz konusu endekslerin ağırlıklı ortalamaları alınarak bileşik endeks elde edilmiştir.

Azerbaycan'da mevduat bankaları, özellikle kamu bankaları kriz sonrası yeniden yapılanma sürecine dâhil olmuşlardır. $\mathrm{Bu}$ bağlamda daha önceki bölümlerde olduğu gibi, yeniden yapılandırmanın ve makroekonomik istikrarın sağlanmasının olumlu etkilerinin 2009 yılından itibaren olumlu etkisini göstermeye başladığı görülmektedir. Merkez Bankasının bağımsız ve enflasyonla mücadeleye odaklanması, sıkı maliye politikası ve yüksek faiz dışı fazla hedeflerinin düzenli olarak tutturulması ekonomik birimlerin beklentilerini ve makro dengeleri olumlu yönde etkilemiştir.

Çalışmada Azerbaycan`da faaliyette bulunan Yerli Sermayeli Ticari Bankalar konu olmaktadır. Çalışmada kullanılan veri seti çalışmada kullanılan bankaların internet sayfasından ve Azerbaycan Devlet İstatistik Komitesinden sağlanmıştır. "Herkese açık” bir veri setiyle çalışılacaktır. Çalışmanın bu bölümünde dezenflasyon sürecinin önemli yıllarını ihata eden 2010 yılından itibaren 2014 y1lı sonuna kadar ticari bankalarının etkinliklerindeki gelişmeler incelenmiştir.

İlk olarak araştırmamızda öncelikle Azerbaycan bankacılık sektöründe faaliyet gösteren tüm mevduat bankalarının yer aldığı 2010 - 2014 yıllarını kapsayan bir performans endeksi oluşturulmuştur. Bundan sonra yerli sermayeli bankalar için aynı dönemi ele alan konsolide bir performans endeksi oluşturulacak ve sırasıyla yerli sermayeli bankalar ile tüm ticaret bankalarının performansları karşılaştırılmıştır. Burada tek tek bankaların performanslarının analizinden kaçınılmıştır. Söz konusu ayrıntılardan kaçınılarak daha makro bir yaklaşımla sektördeki ticaret bankalarının performansı incelenmiştir. Burada yerli bankaların dezenflasyon süreci olarak bilinen 2010-2014 seneleri süresinde gösterdiklerinin performansları ölçülmüştür. Bu bir anlamda ilgili banka gruplarının dezenflasyon sürecindeki faaliyetlerinin performans göstergesi olarak ifade edilebilmektedir.

İlk önce Azerbaycan Bankacılık Sektöründeki Ticaret Bankaları'nın 2010, 2011, 2012, 2013 ve 2014 yıllarına ilişkin CAMELS ana bileşenlerinin alt oranları olacak biçimde toplam 20 finansal oran tespit edilmiştir. CAMELS analizi gereği hem bu finansal oranlara, hem de CAMELS bileşenlerine belirli ağırlıklar verilmiştir. Bu oranların belirlenmesinde ve ağırlıklandırılmasında konu ile ilgili daha önce yapılan çalışmalar, ekonomik konjonktür gereği yaşanan gelişmeler etrafında öne çıkan bileşenler ve sektör temsilcileriyle yapılan görüşmeler dikkate alınmıştır.

Söz konusu finansal oranlar ve ağırlıklandırmalar Tablo 1'de verilmiştir.

Tablo 1: CAMELS Analizinde Kullanılan Finansal Oranlar ve Göstergeler Ağırlıkları

\begin{tabular}{|l|c|}
\hline \multicolumn{1}{|c|}{ CAMELS } & Ăğırlıskenler \\
\hline C-CAPITAL (Sermaye Yeterliliği - SYO) \\
Sermaye / Yükümlülükler (SYO1) & $\mathbf{2 0 \%}$ \\
Özkaynak / Toplam Pasif (SYO2) & $30 \%$ \\
Özkaynak / Toplam Mevduat (SYO3) & $35 \%$ \\
Vergi Öncesi Kar / Toplam Aktifler (SYO4) & $15 \%$ \\
\hline A - ASSET (Varlık Kalitesi - AKO) & $20 \%$ \\
Takipteki krediler(Brüt) / Toplam krediler (AKO1) & $\mathbf{2 0 \%}$ \\
Toplam Krediler / Toplam Aktifler (AKO2) & $25 \%$ \\
\hline
\end{tabular}




\begin{tabular}{|c|c|}
\hline $\begin{array}{l}\text { Toplam Krediler / Toplam Mevduatlar (AKO3) } \\
\text { Duran Aktifler / Toplam Aktifler (AKO4) }\end{array}$ & $\begin{array}{l}20 \% \\
35 \%\end{array}$ \\
\hline M - MANAGEMENT (Yönetim Kalitesi - YYO) & $10 \%$ \\
\hline Takipteki krediler(Net) / Toplam Aktifler (YYO1) & $45 \%$ \\
\hline Şube Başına Net kar (YYO2) & $20 \%$ \\
\hline Faaliyyet Gideri / Toplam Aktifler (YYO3) & $35 \%$ \\
\hline E - EARNINGSS (Karlılık - KO) & $15 \%$ \\
\hline Net Dönem Karı / Ortalama Toplam Aktifler (KO1) & $30 \%$ \\
\hline Net Dönem Karı / Ortalama Özkaynak (KO2) & $25 \%$ \\
\hline Vergi Öncesi Kar/ Ortalama Toplam Aktifler (KO3) & $20 \%$ \\
\hline Toplam Gelirler / Toplam Giderler (KO4) & $25 \%$ \\
\hline L - LİQUİDITTY (Likidite Durumu - LO) & $25 \%$ \\
\hline Likit Aktifler / Toplam Aktifler (LO1) & $50 \%$ \\
\hline Likit Aktifler / Kısa Vadeli Yükümlülükler (LO2) & $50 \%$ \\
\hline S - SENSİTiVITY (Duyarlılık - DO) & $10 \%$ \\
\hline Yabanc1 Para Aktifler / Yabanc1 Para Pasifler (DO1) & $25 \%$ \\
\hline Net Faiz Geliri / Toplam Aktifler (DO2) & $40 \%$ \\
\hline Döviz Pozisyonu / Özzkaynak (DO3) & $35 \%$ \\
\hline TOPLAM & $100 \%$ \\
\hline
\end{tabular}

$\mathrm{Bu}$ aşamada, bankaların seçilen göstergelere göre durumlarının karşılaştırılabilmesi için referans göstergeler hesaplanmıştır. Bunun için öncelikle Azerbaycan'da faaliyet gösteren tüm ticari bankaların her bir yılda ilgili her bir finansal oranı için aritmetik ortalama değeri referans değer olarak hesaplanmıştır. Referans değerler Tablo 2'de verilmiştir.

Tablo 2: CAMELS Analizine Göre Azerbaycan Bankacılık Sektörünün Referans Değerleri

\begin{tabular}{|l|l|l|l|l|l|}
\hline \multicolumn{1}{|c|}{ CAMELS } & \multicolumn{5}{c|}{ Referans Değerleri } \\
\hline Değișkenler & 2010 & 2011 & 2012 & 2013 & 2014 \\
\hline C-CAPITAL & & & & & \\
SYO2 & 0,23 & 0,24 & 0,22 & 0,25 & 0,22 \\
SYO3 & 0,17 & 0,18 & 0,17 & 0,19 & 0,18 \\
SYO4 & 0,31 & 0,32 & 0,29 & 0,33 & 0,33 \\
\hline A-ASSET & 0,01 & 0,02 & 0,02 & 0,02 & 0,02 \\
AKO1 & & & & & \\
AKO2 & 0,17 & 0,19 & 0,20 & 0,17 & 0,16 \\
AKO3 & 0,62 & 0,67 & 0,67 & 0,70 & 0,70 \\
AKO4 & 1,10 & 1,13 & 1,13 & 1,23 & 1,36 \\
\hline M-MANAGEMENT & 0,24 & 0,22 & 0,22 & 0,24 & 0,24 \\
YYO1 & 0,09 & 0,11 & 0,13 & 0,11 & 0,09 \\
YYO2 & 47868 & 97346 & 66789 & 78878 & 61453 \\
YYO3 & 0,05 & 0,05 & 0,05 & 0,05 & 0,05 \\
\hline E- EARNINGS & & & & & \\
KO1 & 0,01 & 0,02 & 0,02 & 0,02 & 0,02 \\
KO2 & 0,03 & 0,09 & 0,09 & 0,12 & 0,11 \\
KO3 & 0,01 & 0,02 & 0,02 & 0,02 & 0,02 \\
KO4 & 1,11 & 1,21 & 1,22 & 1,25 & 1,20 \\
\hline L-LİQUIDİTY & & & & & \\
LO1 & 0,79 & 0,80 & 0,79 & 0,76 & 0,77 \\
LO2 & 3,33 & 3,47 & 3,36 & 3,30 & 3,74 \\
\hline S - SENSITIVITY & & & & & \\
\hline
\end{tabular}




\begin{tabular}{|l|l|l|l|l|l|}
\hline DO1 & 1,35 & 0,94 & 0,99 & 0,92 & 0,97 \\
DO2 & 0,06 & 0,06 & 2,14 & 0,06 & 0,07 \\
DO3 & $-0,10$ & $-0,25$ & $-0,23$ & $-0,22$ & $-0,22$ \\
\hline
\end{tabular}

Genel Azerbaycanca ticari bankalarının referans değerleri belirlendikten sonra her grup bankaların analiz dönemine ait gerçekleşen değerleri hesaplanmaktadır. Bu değerler, her grubu oluşturan bütün bankaların değerlerinin aritmetik ortalaması bulunmasıyla elde ediliyor. Gerçekleşen değerler referans göstergelerine bölünerek 100 ile çarpılarak endeks değeri belirlenecektir. Örneğin 2010 yılı Sermaye Yeterlilik Rasyosunun (Sermaye/Yükümlülükler) referans değeri 0,23 tür. Buna göre Sermaye Yeterlilik Rasyosu 0,24 olan yerli sermayeli bankalar grubunun endeks değeri 106 $(0,23 / 0,24 * 100)$ olmaktadir.

Gerçekleşen değerlerle endeks değerleri kümeleri arasındaki korelasyon katsayıları hesaplanacaktır. Korelasyon katsayısının aldığı değerin eksi veya artı değer almasına göre ilişkinin yönü “+” veya “_“" olarak belirlenecektir. Sapma değeri lişkinin yönü “+” değer aldığı zaman (Sapma değeri = 100-Endeks değeri) formülüyle hesaplanacaktır. İlişkinin yönü “_“ olduğunda ise (Sapma değeri = Endeks değeri-100) formülüyle hesaplanacaktır.

Her bir bileşeni meydana getiren rasyolara ait sapma değerleri ilgili rasyoya ait ağırlık katsayılarıyla çarpılarak CAMELS değerleri elde edilecektir. Elde edilen değerler her bir bileşen bünyesinde toplanacaktır. Bu işlemden elde edilen her toplam, ilgili bileşenin CAMELS değerini ifade edecektir.

İlgili bileşenin tüm göstergeleri için sapma değer hesaplandıktan sonra, her bir bileşeni meydana getiren rasyolara ait sapma değerler ilgili rasyoya ait katsayılarıyla çarpılmaktadır. Elde edilen değerler her bir bileşen bünyesinde toplanmaktadır. Bu işlemden elde edilen her toplam ilgili bileşenin CAMELS değerini vermektedir. Son olarak CAMELS sistemini meydana getiren her bir bileşen için belirlenen ağırlıklar ilgili bileşen değeri ile çarpılmakta ve bu toplam çarpımların toplanmasıyla ulaşılan sonuç CAMELS performansını vermektedir. Analizde kullanılan metodoloji aşağıdaki tabloda özet bir şekilde sunulmuştur.

\subsection{Analiz Sonuçları}

Azerbaycan'da faaliyet gösteren 10 adet yabancı sermayeli bankaların 2010-2014 dönemine ait her bir yıl bazında CAMELS Analizi uygulaması sonuçları tablo halinde aşağıda yer almaktadır:

Tablo 4: Yerli Sermayeli Bankaların 2010-2014 Yılları için CAMELS Analiz Sonuçları

\begin{tabular}{|l|c|c|c|c|c|c|c|}
\hline \multirow{2}{*}{ Değişkenler } & \multirow{2}{*}{ A ğıılık } & \multicolumn{7}{|c|}{ CAMELS Değerleri } \\
\cline { 3 - 8 } & & 2010 & 2011 & 2012 & 2013 & 2014 & Ortalama \\
\hline C-CAPITAL & $\mathbf{2 0} \%$ & $\mathbf{- 1 , 2}$ & $\mathbf{- 1 , 4}$ & $\mathbf{- 1 , 8}$ & $\mathbf{- 3 , 9}$ & $\mathbf{- 2 , 3}$ & $\mathbf{- 2 , 1 2}$ \\
SYO1 & $30 \%$ & $-1,77$ & $-3,9$ & $-4,20$ & $-8,76$ & $-5,85$ & $-4,9$ \\
SYO2 & $35 \%$ & $-0,51$ & $-2,2$ & $-3,23$ & $-7,70$ & $-6,77$ & $-4,1$ \\
SYO3 & $15 \%$ & 0,05 & $-1,6$ & $-1,10$ & $-3,68$ & $-0,55$ & $-1,4$ \\
SYO4 & $20 \%$ & $-3,87$ & 0,85 & $-0,57$ & 0,86 & 1,49 & $-0,2$ \\
\hline A-ASSET & $\mathbf{2 0} \%$ & $\mathbf{1 , 8}$ & $\mathbf{0 , 9}$ & $\mathbf{0 , 8}$ & $\mathbf{- 0 , 1 2}$ & $\mathbf{- 1 , 0}$ & $\mathbf{0 , 5}$ \\
AKO1 & $25 \%$ & 6,57 & 3,24 & 4,88 & 4,89 & $-1,75$ & 3,6 \\
AKO2 & $20 \%$ & $-1,41$ & $-1,1$ & $-0,85$ & 0,02 & 0,21 & $-0,6$ \\
AKO3 & $20 \%$ & 2,73 & 1,07 & 1,64 & $-0,13$ & 1,98 & 1,5 \\
AKO4 & $35 \%$ & 1,00 & 1,1 & $-1,89$ & $-5,42$ & $-5,40$ & $-2,1$ \\
\hline M- MANAGEMENT & $\mathbf{1 0} \%$ & $\mathbf{2 , 3}$ & $\mathbf{1 , 8}$ & $\mathbf{1 , 8}$ & $\mathbf{2 , 5}$ & $\mathbf{- 0 , 6}$ & $\mathbf{1 , 5 6}$ \\
YYO1 & $45 \%$ & 16,6 & 10,9 & 12,03 & 14,4 & $-8,63$ & 9,1 \\
\hline
\end{tabular}




\begin{tabular}{|l|c|c|c|c|c|c|c|}
\hline YYO2 & $20 \%$ & $-3,71$ & $-4,4$ & $-4,02$ & 2,87 & $-5,21$ & $-2,9$ \\
YYO3 & $35 \%$ & 10,1 & 11,2 & 10,12 & 7,8 & 7,99 & 9,4 \\
\hline E - EARNINGS & $\mathbf{1 5} \%$ & $\mathbf{- 3 , 1}$ & $\mathbf{- 0 , 5}$ & $\mathbf{0 , 1 2}$ & $\mathbf{- 0 , 3}$ & $\mathbf{- 1 , 0}$ & $\mathbf{- 0 , 9 6}$ \\
KO1 & $30 \%$ & $-3,29$ & $-2,6$ & 1,08 & 0,17 & $-3,14$ & $-1,6$ \\
KO2 & $25 \%$ & $-16,1$ & $-1,2$ & $-2,56$ & $-3,06$ & $-3,01$ & $-5,2$ \\
KO3 & $20 \%$ & $-2,27$ & $-1,1$ & 0,77 & 0,12 & $-1,77$ & $-0,8$ \\
KO4 & $25 \%$ & 0,82 & 1,66 & 1,51 & 0,99 & 0,99 & 1,2 \\
\hline L- LíUUIDİTY & $\mathbf{2 5} \%$ & $\mathbf{3 , 0}$ & $\mathbf{0 , 7}$ & $\mathbf{3 , 3}$ & $\mathbf{2 , 7}$ & $\mathbf{3 , 3}$ & $\mathbf{2 , 6}$ \\
LO1 & $50 \%$ & $-0,46$ & $-0,8$ & $-1,46$ & $-2,74$ & $-1,25$ & $-1,3$ \\
LO2 & $50 \%$ & 12,3 & 3,4 & 14,68 & 13,7 & 14,26 & 11,7 \\
\hline S- SENSITIVITY & $\mathbf{1 0} \%$ & $\mathbf{1 , 7}$ & $\mathbf{3 , 0}$ & $\mathbf{4 , 2}$ & $\mathbf{1 , 5}$ & $\mathbf{1 , 0}$ & $\mathbf{2 , 2 7}$ \\
DO1 & $25 \%$ & 7,08 & $-0,5$ & 1,94 & $-0,25$ & 1,20 & 1,9 \\
DO2 & $40 \%$ & 11,5 & 12,1 & 39,2 & 7,22 & 6,76 & 15,3 \\
DO3 & $35 \%$ & $-2,02$ & 18,2 & 0,61 & 8,41 & 2,11 & 5,5 \\
\hline TOPLAM & $\mathbf{1 0 0 \%}$ & $\mathbf{4 , 5}$ & $\mathbf{4 , 5}$ & $\mathbf{8 , 4 2}$ & $\mathbf{2 , 4}$ & $\mathbf{- 0 , 6}$ & $\mathbf{3 , 8 1}$ \\
\hline
\end{tabular}

\subsubsection{Sermaye Yeterliliği}

Sermaye Yeterliliği bileşenin en yüsek ağırlığa sahip olan Özkaynak / Toplam Pasif rasyosu, ilgili bileşen bazında yabancı sermayeli bankaların performanslarının çok aşağı çıkmasında önemli bir paya sahiptir. Yalnız 2013 və 2014 yıllarında VÖK / Toplam Aktifler pozitif değerlere sahiptir. Vergilerin de karlılığı etkilediği ve bununla da karın sermayeye aktarımının çok etkili kaldığını söyleyemeyiz.

\subsubsection{Aktif Kalitesi}

Çalışma döneminde bankaların aktif kalitesinde bir düşüş yaşanmıştır. 2010, 2011, 2012 yıllarında pozitif değerler alsa da, bu değerler giderek azalan bir grafik çizmiş ve 2013, 2014 senelerinde düşen grafikle negatif değerlere dönüşmüştür. Bankaların duran varlıklar açısından yetersiz yönetimi bunu etkiledği açık bir şekilde gözükmektedir.

Aktif bileşenin alt rasyolarına bakıldığında analiz dönemi boyunca bir çok değerin pozitif olduğu ortaya çıkmaktadır. Son yıllarda bankaların kredi politikasının çok iyi olduğu gözükmektedir. Kredi miktarının bankada olan mevduat miktarını aşmadığı ve 2014 yılı hariç verilen kredilerin alınmasında sıkıntıların yaşanmadığını söyleye biliriz.

\subsubsection{Yönetim Yeterliliği}

Bileşenin alt rasyolarına dikkat edersek, bileşenin pozitif değer almasında en büyük payı Takipteki Krediler (Net) / Toplam Aktifler ve Faaliyyet Gideri / Toplam Aktifler oranlarıdır. Bu oranların aldığı değerlere istinaden söyleye biliriz ki, yabancı sermayeli bankaların müşterilerinden kredi alımında 2014 hariç zorluklarla karşılaşmamaktadırlar ve bu miktarın, bankaların yedek fonlarını da yüksek bir düzeyde aşmamaktadır. Bununla yanaşı, banka kendi yaşamını sürdürebilmek için yaptığı çalışma ve operasyonlar için düşük bir miktarda faaliyyet giderine ihtiyac duymaktadır. 2014 senesinde krediler konusunda açık şekilde görülecek bir kötüleşme söz konusu olsa da düşük faaliyyet giderleri yine de bankanın karını yükseltmekte devam etmiştir. 


\subsubsection{Kazanç}

Toplam Gelirler/Toplam Giderler rayosu bileşende en yüksek performans gösteren rasyolardan biri olmuştur. Sözkonusu bileşen analiz dönemi boyunca sürekli pozitif değerler almıştır. Diğer rasyolar ise inişli çıkışlı bir performans göstermiştir. Net dönem karının ortalama özkaynaklara ve toplam aktiflere oran1 2012 yılında 2010 yılına göre bir artış göstermiş, sırasıyla -3,29'dan , 1,08'eyükselse de, sonrasında 2014 yılında yeniden -3,14-e düşmüştür.

\subsubsection{Likidite}

Likidite bileşenine ait değerlere bakıldığında, analiz döneminde 2,6 ortalama değer ile yabancı sermayeli bankaların en iyi performans sergilediği bileşen olduğu ortaya çıkmaktadır. En yüksek performansını 2012 ve 2014 yıllarında gösteren ilgili bileşen inceleme dönemi boyunca hep pozitif değerler almıştır. Likidite durumunu temsil eden rasyolardan Likit Aktifler / Kısa Vadeli yükümlülükler rasyosu yüksek pozitif değerler alsa da, Likit Aktifler / Toplam Aktifler rasyosu 5 yıl boyunca sürekli negatif değerler almışlar. Tablodakı değerlerden de görüldüğü gibi yabancı sermayeli bankalar kısa vadeli yükümlülükleri karşısında çok iyi bir durumdalar ve her hangi ters bir durum sözkonusu olduğunda likit kaynaklarla yükümlülüklerini karşılaya bilme imkanlarının olduğu ortada.

\subsubsection{Piyasa Riskine Karşı Duyarlılık}

Yabancı sermayeli mevduat bankacılık grubu duyarlılık performans endeksi tablodan görüldüğü üzere baz yılın üzerinde bir seviyeden sürekli bir düşüş göstererek incelemenin yapıldı̆̆ 1 son dönem olan 2014 yılına gelindiğinde baz yılın altında bir seviyeye gerilediği görülmektedir. Duyarlılık bileşenini oluşturan göstergeler incelendiğinde Net Faiz gelirinin toplam aktifler içindeki payının yüksek olması endeksi artırıcı yönde etki yapmış, bununla birlikte 2010 yılına nazaran 2014 yılında pozitif değere sahip olan Döviz Pozisyonu / Özkaynak rasyosu endeksin artış hızını belli bir miktarda artırmıştır. Kur riskinin oluşması ise endeksin gerilemesine neden olmuştur.

\section{SONUÇ}

Bankalar fon alışverişi amacıyla mevduat toplayan ve topladığı bu mevduatları ihtiyaç sahiplerine satan organizasyonlar olarak düşünülebilir. Günümüzde ekonomik gelişme ve farklılaşmanın etkisiyle bankaların faaliyetlerindeki çeşitlilik artmıştır. Bunun sonucu olarak da bankaların her türlü ekonomik faaliyetin içinde büyük oranda yer aldıkları görülür. Çalışma sonuçlarına göre yerli sermayeli bankaların her yıla ilişkin CAMELS bileşik performans değerleri sermaye yeterliliği hariç sürekli negatif olmuştur. Karlılık bileşeninde ise bankalar oranda kötü bir performans ortaya koymuşlar.

Çalışma sonuçlarına göre yabancı sermayeli bankaların CAMELS bileşik performans değerleri, sermaye ve karlılık bileşenleri dışında sürekli pozitif olmuştur. Yabancı sermayeli bankalar aktif kalitesi, piyasa riskine duyarlılık, yönetim yeterliliği, likidite ve sermaye yeterliliği durumu bileşeni açısından yüksek performans sergilemiştir. Karlılık bileşeninde ise kötü bir performans ortaya koymuşlar. CAMELS bileşenlerini oluşturan rasyolar ve ekonomik konjonktür bazında bir değerlendirme yapıldığında şu sonuçlara ulaşılmaktadır. Azerbaycan bankacılık sektörünün son 5 yıllık dönemde yaşanan temel gelişmeler çerçevesinde değişikliye uğramıştır. Sektör, 2010 öncesinde makroekonomik istikrarsızlıkların yaygın olduğu bir ortamda çok sayıda küçük ölçekli bankanın var olduğu bir yapıya sahip iken, kurumsal yönetim zayıflığı ve risk yönetim ilkelerine uyulmaması gibi nedenlerle yapısal sorunlar yaşamış ve meydana gelen 2008 krizinden sonra belli bir düzeyde etkilenmiştir. Uygulanan yeniden yapılandırma sürecinde sektörün piyasa yapısı gözle görülür 
şekilde değişime uğramıştır. Banka sayısındaki azalmanın yanı sıra bankaların farklı piyasalardaki göreli payları da değişmiştir. Genel olarak 2010-2014 döneminin sonunda gözle görülür bir artış söz konusudur. Ancak ele aldığımız 5 yıllık zaman dilimini, bankaların gelişme düzeyi açısından baktığımızda 2010-2012 yükseliş, 2013 ve 2014 yıllarını ise düşüş dönemleri olmakla ikiye ayıra biliriz. Son iki yılda bir düşüş söz konusu olsa da 2010 yılına göre bir yükselişten bahsede biliriz. Gerek yerli sermayeli gerekse yabancı sermayeli bankaların Azerbaycan bankacılık sektörünün yaşadığı birtakım sorunlar, hukuki altyapının yeterli olmaması, tasarruf birikiminin yetersizliği, dışa bağımlı kaynak yapısı, yeterince çeşitlendirilmemiş finansal ürün ve varlıkların olmaması ve benzeri nedenlerle yeterli bir performans göstermediği görülmektedir.

Görüldüğü gibi, CAMELS analizi, bankaların performansını ölçümlemek açısından objektif sonuçlar verebilecek altyapıya sahip bir yönetim, denetim ve gözetim aracıdır. Bankaların kârlılık, likidite, sermaye yeterliliği gibi ölçülebilen büyüklüklerini analize dâhil ederek hızlı, kolay ve maliyetsiz bir şekilde performans değerlendirmesi yapılmasını sağlayan işlevsel bir araçtır. Bankaların mikro açıdan verimlilikleri, makro açıdan da sağlıklı olmaları önemli bir unsurdur. CAMELS analizi yöntemiyle hem banka düzeyinde hem de makroekonomi genelinde önem taşıyan bileşenlerinin izlenmesi olanağı sağlanmış olmaktadır.

\section{KAYNAKLAR}

Abdullayev, M. (2013). "Türk Bankacılık Sektöründe Dezenflasyon Sürecinde CAMELS Analizi", Dumlupınar Üniversitesi Sosyal Bilimler Dergisi, Sayı: 37, Temmuz 2013.

Akdiş, Muhammet. "Azerbaycan'da Bankacılık ve Mali Kurumlar", İstanbul, Türk Dünyası Araştırmaları Dergisi, Sayı: 99, Aralık 1995.

Akgüç, Ö. (2007). Banka Yönetimi ve Performans Analizi,1.baskı, İstanbul: Arayış Basım ve Yayıncilik.

Akıncı, N. ve Erdoğan, N. (1995). Finansal Tablolar Analizi, 4.baskı, İzmir: Barış Yayınları.

Aras, O.N. (2003). Azerbaycan Ekonomisi: Makro Ekonomik ve Sektörel Analiz, Bakü: Kafkasya Araştırmaları Merkezi Yayınları.

Arıçelik, G. (2010). Ticari Bankalarda Performans Ölçümü CAMELS Analizine Dayalı Bir İnceleme, Dokuz Eylül Üniversitesi, İzmir, Sosyal Bilimler Enstitüsü, İktisat Anabilim Dalı, Yüksek Lisans Tezi.

Atan, M. ve Çatalbaş, G.K. (2005). Bankacılıkta Etkinlik ve Sermaye Yapısının Bankaların Etkinliğine Etkisi, VII. Ulusal Ekonometri ve İstatistik Sempozyumu, Mayıs.

Avkıran, N. (1999). "An Application Reference for Data Envelopment Analysis In Branch Banking: Helping the Novice Researcher", International Journal of Bank Marketing, Vol. 17, № 5.

Azerbaycan Respublikası Bank Sistemi Haqqında Melumat Toplusu, (2000). Bakü: Azerbaycan Banklar Assosasiyası Neşriyyatı.

Berger, A., and Humphrey, D.B. (1997). Efficiency of Financial Institutions: International Survey and Directions for Future Research, The Wharton Financial Institutions Center Working Paper, Vol:5.

Bıkker, J.A. (2004). Competition and Efficiency in a Unified European Banking Market, USA: Edward Elgar Publishing.

Canbaş, S. ve Doğukanl1, H. (2001). Finansal Pazarlar, 3.bask1, İstanbul: Beta Yayınları, 
Çelik, P. (2004). Bankaların Risk Derecelendirmesi, Uzmanlık Yeterlilik Tezi, TCMB, Bankacılık ve Finansal Kuruluşlar Genel Müdürlügü.

Demireli, E., Tükenmez, M., Akkaya, G.C. (2009). Kamu Bankalarında CAMELS Performans Derecelendirme Sistemi Üzerine Bir İnceleme, Afyonkarahisar, 21-24 Ekim 2009, Afyon Kocatepe Üniversitesi, 13. Ulusal Finans Sempozyumu.

Federal Register, Federal Financial Institutions Examination Council, (2001). "Large Banks Supervision", Comptroller's Handbook,. Uniform Financial Institutions Rating System.

Gülcan Ç. ve Shahriyar M. (2014). Azerbaycan Ticari Bankacılık Sektörünün CAMELS Yöntemi İle Performans Analizi, 0dupdudhqlyhuvlwhvlgqhul'hujlvl\&Low6d Ó2fdn,661vv, Marmara Üniversitesi Öneri Dergisi, Cilt 11, Say1 41, Ocak.

İlhan, E., Emre, E., Topaloğlu, Ö. K. (2015). Camels Performans Değerleme Modeli: Türkiye'deki Mevduat Bankaları Üzerine Ampirik Bir Uygulama, Ömer Halisdemir Üniversitesi İktisadi ve İdari Bilimler Fakültesi Dergisi, Cilt 8, Sayı 4.

İnan, E.A. (2000). "Banka Etkinliğinin Ölçülmesi ve Düşük Enflasyon Sürecinde Bankacılıkta Etkinlik", Bankacılar Dergisi, Sayı: 34.

İsmayılov, Z. (1997). Azerbaycan'da Para-Kredi Politikalarının Tarihsel Gelişimi, Bakü: Azerbaycan Devlet İktisat Üniversitesi Yayınları.

Kandemir, T. ve Arıcı, N. D. (1999). Mevduat Bankalarında Camels Performans Türkiye Bankalar Birliği, Bankalarda Kurumsal Yönetim, Ankara: Türkiye Bankalar Birliği Bankacılık ve Araştırma Grubu.

Kaya, Y. T. (2001). Türk Bankacılık Sektöründe CAMELS Analizi, Bankacılık Düzenleme ve Denetleme Kurumu, MSPD Çalışma Raporları: 2001/6 Mali Sektör Politikaları Dairesi Eylül

Meigs, W. B. and Meigs, R.F. (1989). Financial Accounting, $8^{\text {th }}$ edition, New York: Mc Grew Hill.

Memmedov, Z. ve Yeman, A.. (2010). "Azerbaycan'1n Kredi Ve Para Sistemi, Günümüzdeki Özellikleri Ve Gelişme Yönü", Maliyye Finans Yazıları Dergisi, Sayı: 87, Nisan.

Memmedov, Z. F. (2011). Banka Faaliyetleri, Bakü: Azer Neşriyyat.

Memmedov, Z. F. ve Zeynalov, V. (2011). "Küresel Mali Kriz Ortamında Azerbaycan Bankacılık Sektörünün Yapısı, Özellikleri Ve Sorunları", Amme İdare Dergisi, Cilt 44, Sayı: 3, Eylül.

Mercan, M. ve Yolalan R. (2000). "Türk Bankacılı Sisteminde Ölçek ve Mülkiyet Yapıları ile Finansal Performans İlişkisi", İMKB Dergisi, 4. Cilt, Sayı:15.

Mester, J.L. (1999). Efficiency of Banks in The Third Federal Reserve District, The Warton Financial Institutions Center Working Paper.

Muxtarov, Ş. (2012). Azerbaycan Bankacılık Sektörünün CAMELS Perdormans Analizi, Marmara Üniversitesi, İstanbul, Bankacılık ve Sigortacılık Enstitüsü, Bankacılık Anabilim Dalı, Yüksek Lisans Tezi.

Sahajwala, R. and Bergh, P.V. den. (2000). Supervisory Risk Assessment And Early Warning Systems, Bank for International Settlements,Basel Committee on Banking Supervision Working Papers, № 4, December.

Tekinalp, Ü. (1970). Anonim Ortaklığın Bilânçosu ve Yedek Akçeleri, İstanbul: İstanbul Hukuk Fakültesi Yayınevi. 
Timor, M. ve Subaşı, H. (2013). "Banka Şube Hizmet Etkinliklerinin Veri Zarflama Analizi Ve TOPSIS Yöntemleri İle Karşılaştırılması", İ. Ü. İşletme Fakültesi İşletme İktisadi Enstitüsü Yönetim Dergisi, Sayı: 75, Aralık.

\section{Internet Kaynaklar}

Azerbaycan Beynelhalk Bankas1, Y1llı Rapor 2012, Bakü: 2013.www.ibar.az/haqqimizda/maliyyehesabatlari/ (ET:20.02.2016).

Azerbaycan Cumhuriyeti Merkez bankas1, Y1llı Rapor 2002, Bakü, 2003. www.cbar.az/ assets/787/illik_2002.pdf (25.02.2016).

Azerbaycan Cumhuriyeti Merkez Bankas1, Yıllık Rapor 2010, Bakü,2011. www.cbar.az/assets/1889/Illik_hesabat-2011-tam-son.pdf, (ET:25.02.2016).

Azerbaycan Cumhuriyeti Merkez Bankası, Y1llı Rapor 2014, Bakü, 2015. www.cbar.az/assets/3753/illik_hesabat_az2014-_web.pdf (ET:25.02.2016).

Diş Ekonomik İlişkiler Kurumu, Azerbaycan Ülke Raporu 2013, İstanbul, 2014. www.deik.org.tr/KonseyIcerik/5066/Azerbaycan_\%C3\%9Clke_B\%C3\%BClteni.html (ET:03.03.2016)

Federal Deposit Insurance Corporation, Basic Examination Concepts and Guidelines Manual Examination Policies, $\quad$ February 2002. www.fdic.gov/regulations/safety/manual/manual_examinations_full.pdf (ET:18.02.2016).

Federal Deposit İnsurance Corporation, RMS Manual of Examination Policies - Asset Quality, Section 3.1, 2011. www.fdic.gov/regulations/safety/manual/section3-1.pdf (ET:01.03.2016).

http://ithandbook.ffiec.gov/media/22019/occcomptr_handbook_large_bank_superv.pdf (ET:01.03.2016). 